\title{
C-Reactive Protein to Albumin Ratio: A Reliable Marker in Colorectal Cancer
}

\section{Kolorektal Kanser Cerrahisinde Güvenilir Bir Belirteç: C-reaktif Proteinin Albümine Oranı}

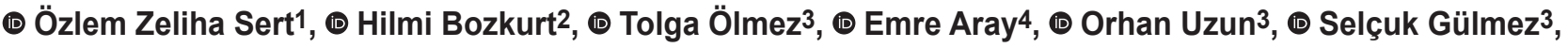

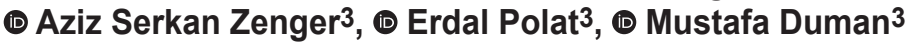

${ }^{1}$ İstanbul Haydarpaşa Training and Research Hospital, Clinic of General Surgery, İstanbul, Turkey

2University of Health Sciences Turkey, Haseki Trainig and Research Hospital, Clinic of General Surgery, İstanbul, Turkey

${ }^{3}$ Kartal Koşuyolu Yüksek İhtisas Trainig and Research Hospital, Clinic of Gastrointestinal Surgery, İstanbul, Turkey

${ }^{4}$ Evliya Çelebi Training and Research Hospital, Clinic of Gastrointestinal Surgery, İstanbul, Turkey

\section{HIIIIII ABSTRACT}

Aim: Postoperative complications after colorectal cancer surgery result in increased treatment costs, prolonged hospital stays and poor prognosis and reduce quality of life of the patients. Here, we aim to contribute to the literature in terms of being a reliable marker of postoperative C-reactive protein (CRP) to albumin ratio (CAR) after colorectal cancer surgery.

Method: A total of 213 patients undergoing colorectal cancer surgery between 2013 and 2018 were analyzed in this study. Risk factors for the development of postoperative complications were analyzed using univariate and multiple logistic regression models. A receiver operating characteristic (ROC) curve analysis was used to analyze the association with the CRP and CAR variables, with the aim being to differentiate postoperative complications.

Results: Postoperative complications occurred in 87 (40.8\%) patients. Based on the Clavien-Dindo classification, 25 (18.7\%) patients developed major complications. Perioperative blood transfusion [odds ratio $(\mathrm{OR})=1.3 ; 95 \%$ confidence interval $(\mathrm{CI})=1.08-1.55$ ] and postoperative $\mathrm{CAR}(\mathrm{OR}=1.2 ; 95 \%$ $\mathrm{CI}=1.05-1.35$ ) were independent risk factors for postoperative complications ( $\mathrm{p}=0.005$ for each). The cut-off value for CAR was 4.3 (sensitivity: 51.72; specificity: 71.43; and area under the curve: 0.642), meaning that CAR was found to be statistically significantly effective in differentiating postoperative complications $(\mathrm{p}<0.001)$. The (median) length of hospital stay was statistically significantly longer in the high CAR $(>4.3)$ group ( $\mathrm{p}=0.001$ ), while the laparoscopic surgery rate was statistically significantly lower in the high CAR group ( $\mathrm{p}=0.039)$.

Conclusion: CAR is a novel, reliable and independent marker. Moreover the ratio is useful for clinicians and provides the determination of early postoperative complications after colorectal cancer surgery.

Keywords: C-reactive protein to albumin ratio, colorectal cancer, postoperative complication

\section{|IIIIIII| ÖZ}

Amaç: Kolorektal kanser cerrahisi sonrası postoperatif komplikasyonlar, tedavi maliyetlerinin artmasına, hastanede kalış sürelerinin uzamasına ve kötü prognoza neden olur ve hastaların yaşam kalitesini düşürür. Burada kolorektal kanser cerrahisi sonrası postoperatif C-reaktif protein (CRP)/ albümin oranının (CAR) güvenilir bir belirteci olması açısından literatüre katkıda bulunmayı hedefliyoruz.

Yöntem: Bu çalışmada 2013-2018 yılları arasında kolorektal kanser cerrahisi geçiren toplam 213 hasta analiz edildi. Postoperatif komplikasyonların gelişimi için risk faktörleri, tek değişkenli ve çoklu lojistik regresyon modelleri kullanılarak analiz edildi. Postoperatif komplikasyonları ayırt etmek amacıyla CRP ve CAR değişkenleri ile ilişkiyi analiz etmek için bir alıcı çalışma özelliği (ROC) eğri analizi kullanıldı.

Bulgular: Seksen yedi $(\% 40,8)$ hastada ameliyat sonrası komplikasyon gelişti. Clavien-Dindo sınıflandırmasına göre 25 (\%18,7) hastada majör komplikasyonlar gelişti. Perioperatif kan transfüzyonu [olasılık oranı $(\mathrm{OO})=1,3$; \%95 güven aralığ $(\mathrm{GA})=1,08-1,55$ ] ve postoperatif $\mathrm{CAR}(\mathrm{OO}=1,2$; \%95 GA= 1,05-1,35) postoperatif komplikasyonlar için bağımsız risk faktörleriydi (her biri için p=0,005). CAR için cut-off değeri 4,3 idi (duyarlılık: 
51,72; özgüllük: 71,43; ve eğri altındaki alan: 0,642), yani CAR'nin postoperatif komplikasyonları ayırt etmede istatistiksel olarak anlamlı derecede etkili olduğu bulundu $(\mathrm{p}<0,001)$. Hastanede kalış süresi (ortanca) yüksek CAR $(>4,3)$ grubunda istatistiksel olarak anlamlı derecede daha uzun iken ( $\mathrm{p}=0,001)$, yüksek CAR grubunda laparoskopik cerrahi oranı istatistiksel olarak anlamlı derecede düşüktü $(\mathrm{p}=0,039)$.

Sonuç: CAR, yeni, güvenilir ve bağımsız bir belirteçtir. Ayrıca oran klinisyenler için yararlıdır ve kolorektal kanser cerrahisi sonrası erken postoperatif komplikasyonların belirlenmesini sağlar.

Anahtar Kelimeler: C-reaktif albümin oranı, kolorektal kanser, postoperatif komplikasyon

\section{Introduction}

Colorectal cancer is the third most commonly diagnosed form of cancer and the fourth leading cause of cancer-related death around the world. ${ }^{1}$ The current curative treatment approach is still surgical resection, despite the improvements in colonoscopic interventions and chemotherapy. ${ }^{2}$ Several complications occur after a surgical resection for colorectal cancer. ${ }^{3,4}$ Such complications result in increased treatment costs, infections, prolonged hospital stays, delayed recovery times and poor prognosis. ${ }^{5,6}$ Accordingly, early identification and the appropriate management of postoperative complications can improve clinical outcomes.

Many factors have been closely linked to cancer, including inflammation and wound healing. ${ }^{7.8}$ Inflammation induces the release of cytokines, inhibits apoptosis and causes DNA injury, contributing to the growth, proliferation, invasion and metastasis of cancer cells. ${ }^{9,10}$ Proinflammatory cytokines increase due to surgical trauma, resulting in changes in the acute phase reactants in the blood, such as albumin and the C-reactive protein (CRP). ${ }^{11}$

Systemic inflammatory response plays an important role in carcinogenesis and tumor progression, and a number of systemic inflammatory markers have been used for its identification, such as neutrophil-to-lymphocyte ratio (NLR), platelet-to-lymphocyte ratio (PLR), Glasgow Prognostic Score (GPS), hemoglobin and albumin levels and lymphocyte and platelet count(HALP) and CRP. Recently, the preoperative $\mathrm{CRP} /$ albumin ratio (CAR) has come into use as a new inflammatory marker for various cancer types. ${ }^{12,13,14,15}$ Literature contains several studies in which preoperative CAR has been used to determine complications following colorectal surgery, although researches investigating postoperative CAR are limited. Among these, the study by Ge et al. ${ }^{11}$ demonstrated that the association between postoperative CAR after colorectal surgery with postoperative complications had a high diagnostic accurac. ${ }^{11}$ The present study contributes to literature by establishing the association of postoperative CAR with postoperative complications among patients who had undergone a curative resection due to colorectal cancer.

\section{Methods}

A retrospective examination was made of 213 patients who had been histopathologically diagnosed with colorectal cancer in a gastrointestinal surgery clinic between 2013 and 2018. The ethics committee of the hospital granted approval for the study (No: 2019.7/06-220), which was conducted in accordance with the principles of the Declaration of Helsinki (revised in 2013). All surgeries were performed by the same group of surgeons. The laboratory results of the preoperative period and the postoperative day 3 were evaluated. The study included patients aged 18 years and older who had been histopathologically diagnosed with colorectal adenocarcinoma, and who underwent curative surgical resection. The study excluded patients who had undergone an R1/R2 resection, and those with liver cirrhosis, those who had perioperatively received an intravenous albumin infusion, those with preoperative systemic infections, those who underwent an additional organ resection and those who underwent repeat surgery within postoperative three days. Data were acquired through demographic characteristics, laboratory tests and surgical characteristics. The demographic characteristics included gender, age, body mass index (BMI), comorbidities (diabetes mellitus [DM], hypertension [HT], coronary artery disease [CAD], chronic obstructive pulmonary disease [COPD]), smoking, American Society of Anesthesiologists (ASA) scores, laparoscopic or open technique, surgery type and sarcopenia. The laboratory tests included preoperative hemoglobin, hematocrit, serum albumin and CRP levels, and postoperative third day levels of CRP and serum albumin.

A recent review has demonstrated that perioperative immunonutrition prevents postoperative complications ${ }^{16}$, and so patients who were administered perioperative immunonutrition in our clinic were also recorded according to the current guidelines. ${ }^{17}$

Furthermore, all patients who received a perioperative blood transfusion, as a possible cause of postoperative complications, were also recorded. The lengths of intensive care unit and hospital stay were recorded to evaluate clinical outcomes. 


\section{Definition of Postoperative Complications}

Complications occurring within 30 days of surgery were defined as postoperative complications. All complications were categorized according to the ClavienDindo classification system. ${ }^{18}$ Accordingly, grade I and II complications were classified as minor complications, and grade III and higher grade complications were classified as major complications. CAR was calculated by dividing the postoperative third day CRP value by the serum albumin value. A Receiver Operating Characteristics (ROC) curve analysis was used to determine the cut-off value for CAR.

Furthermore, the widely-accepted Charlson Comorbidity Index (CCI) was used to assess the effects of patient comorbidities. CCI is mostly used to estimate survival in cancer patients, although a number of researchers have found it to be useful also for estimating the clinical outcomes of colon cancer patients. ${ }^{19,20}$

\section{Statistical Analysis}

The study data were summarized as tabular descriptive statistics and expressed as mean \pm standard deviation or median (IQR) for continuous variables. Categorical variables were expressed as numbers and percentages. Numerical variables were tested for normality using a Kolmogorov-Smirnov test. An Independent Samples t-test and a Mann-Whitney $U$ test were used for the comparison of two independent groups for normally and non-normally distributed numerical variables, respectively. Pearson's Chi-Square or Fisher's Exact Tests were used to compare categorical variables for differences. Risk factors for the development of postoperative complications were analyzed using univariate and multiple logistic regression models, and the results were presented as odds ratio and at a 95\% confidence interval.

A ROC curve analysis was used to analyze the association with the CRP and CAR variables, with the aim being to differentiate postoperative complications. The optimal cut-off values, 95\% confidence interval and area under the curve (AUC) were calculated based on Youden's index using DeLong's method in the MedCalc Statistical Software Trial version (MedCalc Software bvba, Ostend, Belgium; http:// www.medcalc.org; 2015) program. Statistical analyses were carried out using Jamovi (Version 1.0.7) and JASP (version 0.11 .1 ) software, and a p-value of 0.05 was considered significant in the statistical analyses.

\section{Results}

The mean age of study participants was $61.3 \pm 13.2$ years. Among study participants, there were 119 male and 94 female patients. Postoperative complications occurred in 87
(40.8\%) patients. Based on the Clavien-Dindo classification, 25 (18.7\%) patients developed major complications. Additionally, 42 (19.7\%) patients developed surgical site infections. The median length of hospital stay was 8 days.

Table 1 presents a comparison of certain demographic and clinical characteristics and the development of postoperative complications. A univariate analysis revealed that the development of complications was statistically significantly associated with length of stay in the intensive care unit, the length of hospital stay, perioperative blood transfusion and laparoscopic surgery. Patients with postoperative complications had longer stays in both intensive care and hospital. Furthermore, postoperative complications were statistically significantly associated with lower postoperative albumin levels and higher postoperative third day CRP and CAR levels ( $p=0.032, p=0.001$, respectively). None of the other comparisons revealed any statistically significant differences ( $\mathrm{p}>0.05$ for each, Table 1).

Table 2 presents the cut-off values, calculated using a ROC analysis based on the CRP and CAR variables and the influence on postoperative complication development. Accordingly, the cut-off value for CRP was 7.9 (sensitivity: 86.21; specificity: 36.51; and AUC: 0.646), meaning that CRP was statistically significantly effective in differentiating postoperative complications $(\mathrm{p}<0.001)$ (Figure 1). Furthermore, the cut-off value for CAR was 4.3 (sensitivity: 51.72; specificity: 71.43; and AUC: 0.642), meaning that CAR was found to be statistically significantly effective in differentiating postoperative complications $(p<0.001)$. The comparison of the AUC values for CPR and CAR revealed no superiority between the two $(\mathrm{p}=0.769)$.

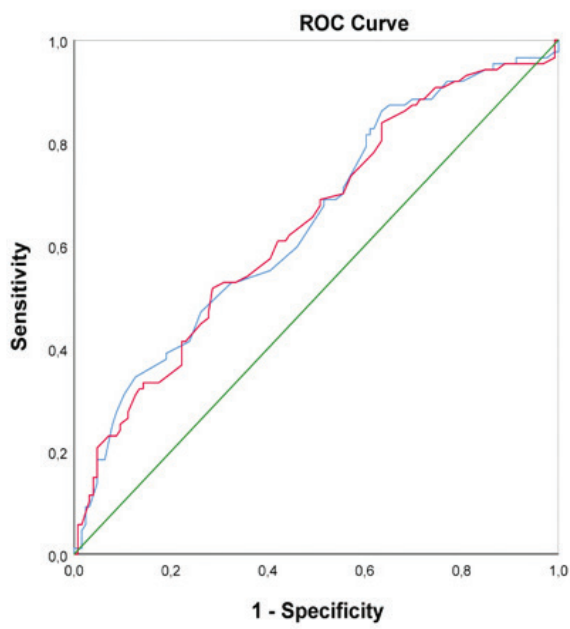

Source of the Curve CRP (Postoperative day three) - CRP / Albumin Ratio (Postoperative day three) - Reference Line

Figure 1. ROC curve analysis of postoperative $3^{\text {rd }}$ day CRP and CAR values

CRP: C-reactive protein, CAR: C-reactive protein to albumin ratio 
Table 1. Comparison of certain demographic and clinical characteristics and the development of postoperative complications

\begin{tabular}{|c|c|c|c|c|}
\hline & & Postoperative compli & & \\
\hline & All $(n=213)$ & No $(n=126)$ & Yes $(n=87)$ & p-value \\
\hline Age & $61.3 \pm 13.2$ & $60.2 \pm 12.3$ & $62.9 \pm 14.3$ & $0.158^{*}$ \\
\hline Gender (\%) & & & & \\
\hline Male & $119(55.9)$ & $71(56.3)$ & $48(55.2)$ & \\
\hline Female & $94(44.1)$ & $55(43.7)$ & $39(44.8)$ & 0.910 \\
\hline BMI (\%) & & & & \\
\hline$<25$ & $69(32.4)$ & $45(35.7)$ & $24(27.6)$ & \\
\hline$\geq 25$ & $144(67.6)$ & $81(64.3)$ & $63(72.4)$ & 0.215 \\
\hline Smoking (\%) & $56(26.4)$ & $37(29.6)$ & $19(21.8)$ & $0.270 * *$ \\
\hline Perioperative immunonutrition (\%) & $103(48.4)$ & $65(51.6)$ & $38(43.7)$ & $0.319 * *$ \\
\hline Sarcopenia (\%) & $82(42.7)$ & $47(41.2)$ & $35(44.9)$ & $0.724 * *$ \\
\hline HT (\%) & $69(32.4)$ & $37(29.4)$ & $32(36.8)$ & $0.323 * *$ \\
\hline DM (\%) & $45(21.1)$ & $27(21.4)$ & $18(20.7)$ & $0.999 * *$ \\
\hline COPD (\%) & $14(6.6)$ & $5(4.0)$ & $9(10.3)$ & $0.118 * *$ \\
\hline $\mathrm{CAD}(\%)$ & $42(19.7)$ & $24(19.0)$ & $18(20.7)$ & $0.904 * *$ \\
\hline Intensive care unit stay (day), (median) & $1.0[1.0-1.0]$ & $1.0[1.0-1.0]$ & $1.0[1.0-1.0]$ & $0.001 * * *$ \\
\hline Length of hospital stay (day), (median) & $8.0[7.0-14.0]$ & $7.0[6.0-8.0]$ & $15.0[12.0-20.0]$ & $0.001 * * *$ \\
\hline Operation time (min), (median) & $210.0[160.0-250.0]$ & $220.0[166.2-250.0]$ & $210.0[160.0-260.0]$ & $0.931 * * *$ \\
\hline Perioperative blood transfusion (median) & $0.0[0.0-2.0]$ & $0.0[0.0-2.0]$ & $1.0[0.0-2.5]$ & $0.003 * * *$ \\
\hline Anterior resection (\%) & $42(19.7)$ & $24(19.0)$ & $18(20.7)$ & $0.904 * *$ \\
\hline Low anterior resection (\%) & $74(34.7)$ & $43(34.1)$ & $31(35.6)$ & $0.936 * *$ \\
\hline Right hemicolectomy (\%) & $57(26.8)$ & $32(25.4)$ & $25(28.7)$ & $0.701^{* *}$ \\
\hline Left hemicolectomy (\%) & $19(8.9)$ & $13(10.3)$ & $6(6.9)$ & $0.538 * *$ \\
\hline Subtotal colectomy (\%) & $5(2.3)$ & $2(1.6)$ & $3(3.4)$ & $0.401^{* *}$ \\
\hline Total colectomy (\%) & $1(0.5)$ & $1(0.8)$ & $0(0.0)$ & $0.999 * *$ \\
\hline Transverse colectomy (\%) & $3(1.4)$ & $3(2.4)$ & $0(0.0)$ & $0.272 * *$ \\
\hline Loop ileostomy (\%) & $45(21.1)$ & $23(18.3)$ & $22(25.3)$ & $0.287^{* *}$ \\
\hline Miles (\%) & $12(5.6)$ & $8(6.3)$ & $4(4.6)$ & $0.765^{* *}$ \\
\hline Harttman (\%) & $2(0.9)$ & $1(0.8)$ & $1(1.1)$ & $0.999 * *$ \\
\hline Laparoscopic (\%) & $52(24.4)$ & $39(31.0)$ & $13(14.9)$ & $0.012 * *$ \\
\hline $\mathrm{ASA} \geq 3(\%)$ & $141(66.2)$ & $81(64.3)$ & $60(69.0)$ & $0.574 * *$ \\
\hline Charlson Comorbidity Index (median) & $3.0[2.0-4.0]$ & $3.0[2.0-4.0]$ & $4.0[2.0-5.0]$ & $0.057 * * *$ \\
\hline Charlson Comorbidity Index (\%) & & & & \\
\hline$\geq 2$ & $174(81.7)$ & $101(80.2)$ & $73(83.9)$ & $0.606^{* *}$ \\
\hline$<2$ & $39(18.3)$ & $25(19.8)$ & $14(16.1)$ & $0.606 * *$ \\
\hline Preoperative hematocrit & $34.9 \pm 5.6$ & $35.4 \pm 5.8$ & $34.3 \pm 5.3$ & $0.188 *$ \\
\hline Preoperative albumin (mg/dL) & $4.1 \pm 0.5$ & $4.1 \pm 0.5$ & $4.1 \pm 0.4$ & $0.580 *$ \\
\hline Preoperative CRP (mg/dL), (median) & $0.7[0.3-1.7]$ & $0.6[0.3-1.4]$ & $0.8[0.3-1.9]$ & $0.252 * * *$ \\
\hline Albumin (Postoperative $3^{\text {rd }}$ day) & $3.0 \pm 0.4$ & $3.1 \pm 0.4$ & $3.0 \pm 0.4$ & $0.032 *$ \\
\hline CRP (Postoperative $3^{\text {rd }}$ day), (median) & $11.0[7.8-16.0]$ & $10.0[6.0-14.0]$ & $13.0[9.0-19.5]$ & $0.001^{* * *}$ \\
\hline CAR (Postoperative $3^{\text {rd }}$ day), (median) & $3.6[2.4-5.3]$ & $3.2[1.9-4.8]$ & $4.4[2.8-6.2]$ & $0.001^{* * *}$ \\
\hline
\end{tabular}

BMI: Body mass index, HT: Hypertension, DM: Diabetes mellitus, COPD: Chronic obstructive pulmonary disease, CAD: Coronary artery disease, CRP: C-reactive protein 
Based on the CAR cut-off value, 132 patients were classified as low CAR $(\leq 4.3)$ and 81 patients as high CAR $(>4.3)$ groups. Table 3 presents a comparison of certain clinical parameters by CAR. Accordingly, the (median) length of hospital stay was statistically significantly longer in the high CAR (>4.3) group ( $\mathrm{p}=0.001)$, while the laparoscopic surgery rate was statistically significantly lower in the high CAR group ( $\mathrm{p}=0.039)$.

A multivariate analysis model was then applied to determine the risk factors from the univariate analysis that were independently associated with postoperative complications (Table 4). First, a univariate logistic regression model was analyzed, and all variables included in the model were found to be statistically significant ( $\mathrm{p}<0.05$ for each, Table 4). An analysis of the multiple logistic regression model revealed that perioperative blood transfusion (OR=1.3; 95\% $\mathrm{CI}=1.08-1.55)$ and $\mathrm{CAR}(\mathrm{OR}=1.2 ; 95 \% \mathrm{CI}=1.05-1.35)$ were independent risk factors for postoperative complications $(\mathrm{p}=0.005$ for each).

\section{Discussion}

The present study demonstrated postoperative CAR to be an independent and a significant risk factor for postoperative complications among 213 patients who underwent curative

Table 2. ROC analysis results of postoperative complication based on CRP and CAR variables

\begin{tabular}{llllllll} 
& AUC & Sensitivity & Specificity & Cut-Off & $95 \%$ CI & p-value & $\begin{array}{l}\text { Pairwise comparison } \\
\text { of ROC curves p-value }\end{array}$ \\
\hline CRP & 0.646 & 86.21 & 36.51 & $>7.9$ & $0.578-0.710$ & $<0.001$ & 0.769 \\
CAR & 0.642 & 51.72 & 71.43 & $>4.3$ & $0.574-0.706$ & $<0.001$ &
\end{tabular}

CRP: C-reactive protein, CAR: C-reactive protein to albumin ratio, CI: Confidence interval, ROC: Receiver operating characteristic, AUC: Area under the curve

Table 3. Comparison of certain clinical parameters based on CAR levels of patients

\begin{tabular}{|c|c|c|c|c|}
\hline & & CAR & & \\
\hline & All $(n=213)$ & $\leq 4.3(n=132)$ & $>4.3(\mathrm{n}=81)$ & $\mathrm{p}$ \\
\hline \multicolumn{5}{|l|}{ BMI (\%) } \\
\hline$<25$ & $69(32.4)$ & $45(34.1)$ & $24(29.6)$ & $0.600 *$ \\
\hline$\geq 25$ & $144(67.6)$ & $87(65.9)$ & $57(70.4)$ & \\
\hline Smoking (\%) & $56(26.4)$ & $35(26.7)$ & $21(25.9)$ & $0.999 *$ \\
\hline Perioperative immunonutrition (\%) & $103(48.4)$ & $64(48.5)$ & $39(48.1)$ & 0.999* \\
\hline Sarcopenia (\%) & $82(42.7)$ & $50(42.4)$ & $32(43.2)$ & $0.999 *$ \\
\hline $6^{\text {th }}$ month survival (\%) & $6(2.8)$ & $3(2.3)$ & $3(3.7)$ & $0.676^{*}$ \\
\hline HT (\%) & $69(32.4)$ & $41(31.1)$ & $28(34.6)$ & $0.704^{*}$ \\
\hline DM (\%) & $45(21.1)$ & $28(21.2)$ & $17(21.0)$ & $0.999 *$ \\
\hline COPD (\%) & $14(6.6)$ & $10(7.6)$ & $4(4.9)$ & $0.639 *$ \\
\hline CAD (\%) & $42(19.7)$ & $24(18.2)$ & $18(22.2)$ & $0.588 *$ \\
\hline Intensive care unite (day), (median) & $1.0[1.0-1.0]$ & $1.0[1.0-1.0]$ & $1.0[1.0-1.0]$ & $0.775^{* *}$ \\
\hline Length hospital stay (day), (median) & $8.0[7.0-14.0]$ & $8.0[7.0-11.0]$ & $10.0[7.0-16.0]$ & $0.001 * *$ \\
\hline Laparoscopic (\%) & $52(24.4)$ & $39(29.5)$ & $13(16.0)$ & $0.039 *$ \\
\hline \multicolumn{5}{|l|}{ Charlson Comorbiditiy Index (\%) } \\
\hline$\geq 2$ & $174(81.7)$ & $103(78.0)$ & $71(87.7)$ & $0.114^{*}$ \\
\hline$<2$ & $39(18.3)$ & $29(22.0)$ & $10(12.3)$ & \\
\hline \multicolumn{5}{|l|}{ Clavian dindo (\%) } \\
\hline$<3$ & $109(81.3)$ & $65(86.7)$ & $44(74.6)$ & $0.119 *$ \\
\hline$\geq 3$ & $25(18.7)$ & $10(13.3)$ & $15(25.4)$ & \\
\hline
\end{tabular}

BMI: Body mass index, HT: Hypertension, DM: Diabetes mellitus, COPD: Chronic obstructive pulmonary disease, CAD: Coronary artery disease, 
Table 4. Univariate and multiple logistic regression analyses of the factors affecting postoperative complication development

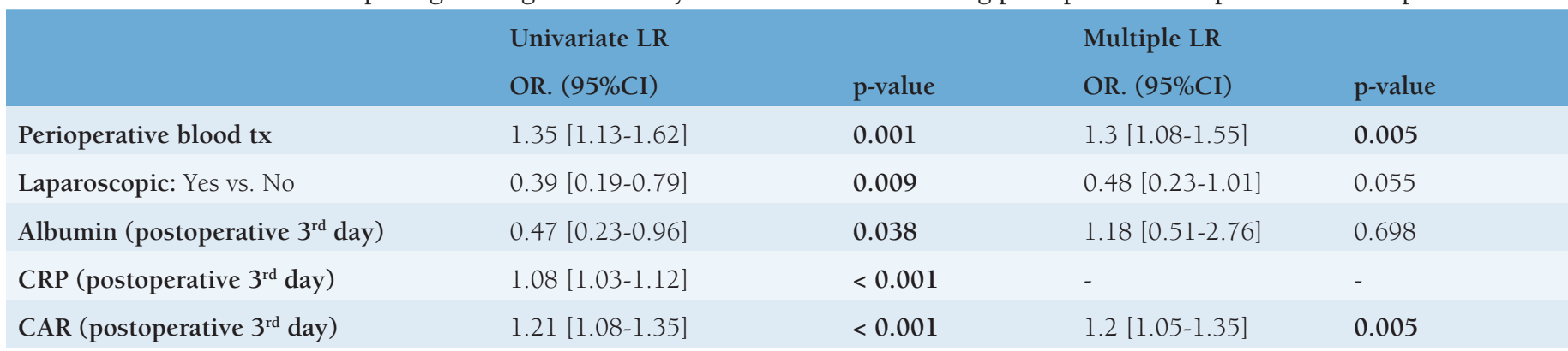

Dependent variable: Presence of Post-op complication. Bold p values were considered statistically significant (p<0.05). OR: Odds ratio, LR: Logistic regression, CI: Confidence interval, $\mathrm{CRP}$ was not included in the multiple model due to multicollinearity problems.

CRP: C-reavtive protein

surgical resection due to colorectal cancer. Furthermore, the ROC analysis revealed that high CAR values prolonged the hospital stays, and that postoperative CAR was higher in patients who had not undergone laparoscopic surgery.

CRP is an acute phase reactant that is synthesized by the liver. Elevated CRP serum levels induce the release of the inflammatory cytokines associated with cancer. In addition, serum albumin level is a commonly used marker for nutritional status, and is associated with the chronic inflammatory process that activates cytokines like IL- 1 and TNF- $\alpha .{ }^{21,22}$ Recent studies have demonstrated that a systemic inflammatory response after surgical trauma is associated with poor outcomes, which was established with serum levels of CRP and albumin. ${ }^{23,24} \mathrm{~A}$ recent study reported that CRP alone was not a sufficient determining factor indicating inflammation in the early postoperative period..$^{25}$

Ge et al. conducted a study to determine postoperative complications in the early period after colorectal surgery, and established a ratio using CRP and albumin together. They found that the postoperative third day CAR value had a higher diagnostically accurate association with postoperative complications than CRP (predictive value [PPV] for CRP: 79.1\%; PPV for CAR: $81.4 \%$ ). Additionally, the CAR cutoff value was found to be 2.2, and an independent risk factor for postoperative complications (AUC of CAR was 0.779 , sensitivity was 0.748 , specificity was 0.695$).{ }^{11} \mathrm{~A}$ recent study by Man et al., in turn, compared modified GPS, CAR, postoperative GPS and CRP values to determine postoperative complications after colorectal cancer surgery. The authors reported that the postoperative third day CAR value was more useful than the other markers among all of these scoring systems (AUC: 0.711, PPV: 83.2\%); the cut-off value was 2.6 (sensitivity: $51.3 \%$, specificity: $87.8 \%$ ); and the postoperative complication rate was higher in those with high CAR $(\geq 2.6)$ values. ${ }^{26}$
Our study had a larger sample size than the two similar studies identified, but established a postoperative complication rate that was lower than those two studies (40.8\%). ${ }^{11,26}$ Different to these studies, we found the CAR cut-off value to be 4.3 (sensitivity: 51.72 , specificity: 71.43 , and AUC: 0.642). Despite the lower specificity and AUC values, the multiple logistic regression analysis revealed CAR to be an independent risk factor for postoperative complications, which was consistent with other studies. Furthermore, an AUC value of $>0.5$ is statistically a good predictor of postoperative complications. Other studies. ${ }^{11,26}$ found major and minor postoperative complications, based on the Clavien-Dindo classification, to be statistically significantly lower in the low CAR group, whereas no statistically significant association was identified between patients with postoperative minor and major complications, and CAR in the present study. On the other hand, our study reported longer hospital stays and lower laparoscopic surgery rates in the high CAR group.

Once again, the studies by Man et al. ${ }^{26}$, and Ge et al. ${ }^{11}$ failed to identify any statistically significant association between laparoscopic surgery and postoperative complications, while the present study identified a lower postoperative complication rate among patients undergoing laparoscopic surgery. In a similar vein, literature contains a number of studies reporting reduced postoperative complication rates and shortened hospital stays with laparoscopic surgery when compared to open surgery. ${ }^{27,28}$

Another point to emphasize about the present study is the identification of a perioperative blood transfusion as an independent risk factor for postoperative complications. In a recent meta-analysis it was indicated that transfusions can lead to infections, and pulmonary, cardiac, anastomotic and overall complications among patients undergoing colorectal cancer surgery. ${ }^{29}$ 
Although there was no statistically significant association between CCI and postoperative complications ( $\mathrm{p}=0.057$ ), postoperative complications were found to be more common among patients with a higher median $\mathrm{CCI}$ value $(>3)$. Similar to the present study, Huang et al. ${ }^{20}$ reported more postoperative complications in the group with $\mathrm{CCI} \geq 3$ among elderly colorectal cancer patients who had undergone laparoscopic surgery. ${ }^{20}$

Additionally, two recent meta-analyses reported high preoperative CAR to be associated with poor prognosis and disease-free survival in colorectal cancer patients. ${ }^{30,31}$ Our study made no investigation of the link with survival, although further studies may analyze the relationship between postoperative CAR and prognosis and disease-free survival in colorectal cancer patients.

\section{Study Limitations}

There are some limitations in the present study, first and foremost among which is its retrospective, singlecenter design. Second, CAR was not compared with other inflammatory scoring systems, and so it could not be established whether or not it was superior to other markers. As such, there is a need for prospective, multi-center and large-scale studies with a larger sample size for the comparison of other markers.

\section{Conclusion}

Despite the lack of comparison with other inflammatory markers, CAR is an easy to use and independent ratio for clinicians that allows the early postoperative determination of complications. Especially today, when there are still high postoperative complication rates after colorectal surgery, it is of vital importance to identify and manage postoperative complications in the early period with a view to shortening hospital stays, decreasing hospital costs and improving the quality of life of patients.

\section{Ethics}

Ethics Committee Approval: The ethics committee of the hospital granted approval for the study (no: 2019.7/06-220), which was conducted in accordance with the principles of the Declaration of Helsinki (revised in 2013).

Informed Consent: The informed consent was given by all the participated patients.

Peer-review: Externally and internally peer reviewed.

\section{Authorship Contributions}

Design: Ö.Z.S., E.P., M.D., Data Collection or Processing:H.B., T.Ö., E.A., O.U., Analysis or Interpretation: S.G., A.S.Z., Writing: Ö.Z.S

Conflict of Interest: No conflict of interest was declared by the authors.
Financial Disclosure: The authors declared that this study received no financial support.

\section{References}

1. Torre LA, Bray F, Siegel RL, Ferlay J, Lortet-Tieulent J, Jemal A. Global cancer statistics, 2012. CA Cancer J Clin 2015;65:87-108.

2. Schmoll HJ, VanCutsem E, Stein A, Valentini V, Glimelius B, Haustermans K, Nordlinger B,van de Velde CJ, Balmana J, Regula J, Nagtegaal ID, Beets Tan RG, Arnold D, Ciardiello F, Hoff P, Kerr D, Köhne CH, Labianca R, Price T, Scheithauer W, Sobrero A, Tabernero J, Aderka D, Barroso S, Bodoky G, Douillard JY, El Ghazaly H, Gallardo J, Garin A, Glynne-Jones R, Jordan K, Meshcheryakov A, Papamichail D Pfeiffer P, Souglakos I, Turhal S, Cervantes A. ESMO consensus guidelines for management of patients with colon and rectal cancer, a personalized approach to clinical decision making, Ann Oncol 2012;23:2479-2516.

3. Warschkow R, Beutner U, Steffen T, Muller SA, Schmied BM, Güller U, Tarantino I. Safe and early discharge after colorectal surgery due to C-reactive protein: a diagnostic meta-analysis of 1832 patients. Ann Surg 2012:256:245-250.

4. Zhang T, Cao L, Cao T, Yang J, Gong J, Zhu W, Li N, Li J. Prevalence of sarcopenia and its impact on postoperative outcome in patients with Crohn's disease undergoing bowel resection. JPEN J Parenter Enteral Nutr 2017:41:592-600

5. Krarup PM, Nordholm-Carstensen A, Jorgensen LN, Harling $H$. Anastomotic leak increases distant recurrence and long-term mortality after curative resection for colonic cancer: a nationwide cohort study. Ann Surg 2014;259:930-938.

6. Ortega-Deballon P, Radais F, Facy O, D'Athis P, Masson D, Charles PE, Ciheynel N, Favre J-P, Rat P. C-reactive protein is an early predictor of septic complications after elective colorectal surgery. World J Surg 2010;34:808-814

7. Balkwill F, Mantovani A. Inflammation and cancer: back to Virchow? Lancet 2001;357:539-545.

8. Mantovani A, Allavena P, Sica A, Balkwill F. Cancer-related inflammation. Nature 2008;454:436-444.

9. Jaiswal M, LaRusso NF, Burgart LJ, Gores GJ. Inflammatory cytokines induce DNA damage and inhibit DNA repair in cholangiocarcinoma cells by a nitric oxide-dependent mechanism. Cancer Res 2000;60:184-190.

10. Yang J, Wezeman M, Zhang X, Lin P, Wang M, Qian J, Wan B, Kwak LW, Yu L, Yi Q . Human C-reactive protein binds activating Fc gamma receptors and protects myeloma tumor cells from apoptosis. Cancer Cell 2007; 12:252-265

11. Ge X, Cao Y, Wang H, Ding C, Tian H, Zhang X, Gong J, Zhu W, Li N. Diagnostic accuracy of the postoperative ratio of C-reactive protein to albumin for complications after colorectal surgery. World J of Surg Oncol 2017;15:15

12. Roxburgh Campbell SD, McMillan Donald C. Role of systemic inflammatory response in predicting survival in patients with primary operable cancer Future Oncol 2010;6:149-163.

13. Kinoshita A, Onoda H, Imai N, Iwaku A, Oishi M, Tanaka K, Fushiya N, Koike K, Nishino H, Matsushima M. The C-reactive protein/albumin ratio, a novel inflammation-based prognostic score, predicts outcomes in patients with hepatocellular carcinoma. Ann Surg Oncol 2015;22:803-810.

14. Yalav O, Topal U, Unal AG, Eray IC and Rencuzogullarn A. Clinical Value of Neutrophil/Lymphocyte Ratio in Predicting Postoperative Complications and Prognosis in Patients with Colorectal Cancer Undergoing Surgical Treatment. Turk J Colorectal Dis 2020;30:49-56.

15. Yalav O, Topal U, Unal AG, Sarttas AG. Clinical Value of Hemoglobin and Albumin Levels and Lymphocyte And Platelet Count (HALP) Combination in Predicting Postoperative Complications, Lymph Node Positivity and Prognosis in Gastric Cancer Patients Who Underwent Curative Surgical Resection. Cyprus J Med Sci 2020;5:145-152. 
Sert et al.

16. Fukatsu K. Role of nutrition in gastroenterological surgery. Ann Gastroenterol Surg 2019;3:160-168.

17. Weimann A, Braga M, Carli F, Higashiguchi T, Hübner M, Klek S, Laviano A, Ljungqvist O, Lobo DN, Martindale R, Waitzberg DL, Bischoff SC, Singer P. ESPEN guideline: clinical nutrition in surgery. Clin Nutr 2017;36:623650

18. Clavien PA, Barkun J, de Oliveira ML, Vauthey JN, Dindo D, Schulick RD, de Santibañes E, Pekolj J, Slankamenac K, Bassi C, Graf R, Vonlanthen R, Padbury R, Cameron JL, Makuuchi M. The Clavien-Dindo classification of surgical complications five-year experience. Ann Surg 2009;250:187-196.

19. Chang CM, Yin WY, Wei CK, Wu CC, Su YC, Lee C. Adjusted Age-Adjusted Charlson Comorbidity Index Score as a Risk Measure of Perioperative Mortality before Cancer Surgery. PLoS One 2016;11:e0148076

20. Huang Y, Zhang Y, Li J, Liu G. Charlson comorbidity index for evaluation of the outcomes of elderly patients undergoing laparoscopic surgery for colon cancer. JBUON 2017;22:687.

21. Chojkier M. Inhibition of albumin synthesis in chronic diseases: molecular mechanisms. J Clin Gastroenterol 2005;39:S143-S146.

22. Oñate-Ocaña LF, Aiello-Crocifoglio V, Gallardo-Rincón D, HerreraGoepfert R, Brom-Valladares R, Carrillo JF, Cervera E, Mohar-Betancourt A. Serum albumin as a significant prognostic factor for patients with gastric carcinoma. Ann Surg Oncol 2007;14:381-389.

23. Hubner M, Mantziari S, Demartines N, Pralong F, Coti-Bertrand P, Schafer M. Postoperative albumin drop is a marker for surgical stress and a predictor for clinical outcome: a pilot study. Gastroenterol Res Pract. 2016;2016:8743187.

24. Angiolini MR, Gavazzi F, Ridolfi C, Moro M, Morelli P, Montorsi M, Zerbi A. Role of C-reactive protein assessment as early predictor of surgical site infections development after pancreaticoduodenectomy. Dig Surg 2016;33:267-275

25. Rettig TC, Verwijmeren L, Dijkstra IM, Boerma D, van de Garde EM, Noordzij PG. Postoperative interleukin-6 level and early detection of complications after elective major abdominal surgery. Ann Surg 2016;263:1207-1212.

26. Man Lin H, Liu Z, Jin L, Wang J, Zhang J, Bai Z, Yao H, Zhang Z, Deng W. Usefulness of inflammation-Based Prognostic Scores for Predicting the Risk of Complications after radical resection of colorectal carcinoma. Cancer Management and Research 2020;12:1029-1038.

27. Zaharie F, Ciorogar G, Zaharie R, Mocan T, Zdrehus C, Mocan L, Berindan-Neagoe I, Achimas P, Cornel Iancu, Tomus C. Laparoscopic rectal resection versus conventional open approach for rectal cancer - a 4-year experience of a single center. JBUON 2015;20:1447-1455.

28. Krarup PM, Nordholm-Carstensen A, Jorgensen LN, Harling H. Association of Comorbidity with Anastomotic Leak, 30-day Mortality, and Length of Stay in Elective Surgery for Colonic Cancer: A Nationwide Cohort Study. Dis Colon Rectum 2015;58:668-676.

29. Pan QY, An R, Liu HL. Perioperative transfusion and the prognosis of colorectal cancer surgery: a systematic review and meta-analysis. World J Surg Oncol 2019;17:7.

30. Wang F, Li P, Li F. Prognostic role of C-reactive protein to albumin ratio in colorectal cancer. Medicine 2019;98:29.

31. Xu H, Ma Y, Deng F, Ju W, Sun X, Wang H. The prognostic value of C-reactive protein/albumin ration in human malignancies: un updated meta analysis. OncoTargets and Therapy 2017:10. 